\title{
Perspective of Business Models and Innovation for Sustainability Transition in Hospitals
}

\author{
Catia Milena Lopes ${ }^{1}{ }^{\mathbb{D}}$, Annibal José Scavarda ${ }^{2}$, Guilherme Luís Roehe Vaccaro ${ }^{1}{ }^{(}$, \\ Christopher Rosa Pohlmann ${ }^{1}$ 遖 and André Luis Korzenowski ${ }^{1,3, *}$ \\ 1 Polytechnic School, University of Vale do Rio dos Sinos (UNISINOS), São Leopoldo 93020-190, Brazil; \\ catia.milena.lopes@gmail.com (C.M.L.); guilhermevaccaro@gmail.com (G.L.R.V.); \\ chrispohlmann@gmail.com (C.R.P.) \\ 2 School of Production Engineering, Federal University of the State of Rio de Janeiro, Rio de Janeiro 22451-070, \\ Brazil; annibal.scavarda@unirio.br \\ 3 Business School, University of Vale do Rio dos Sinos (UNISINOS), Porto Alegre 91330-002, Brazil \\ * Correspondence: akorzenowski@unisinos.br
}

Received: 20 November 2018; Accepted: 17 December 2018; Published: 20 December 2018

check for updates

\begin{abstract}
Hospitals have valuable resources but are have facedsignificant changes over recentdecades. The adoption of principles that drive the strategic development of business models as innovation is imperative in these institutions. This research study aims to articulate a conceptual review of business models, innovation, and sustainability transition in the context of health business. It proposes a model for future applications in hospitals. This proposed model emphasizes the relations that arise under the multiple-level perspective. It also addresses the evolution of the concepts of business models and innovation that might contribute to the sustainability transition movement once new sociotechnical systems get space in these organizations. The main results of this conceptual review are the multiple depictions of internal and external elements that mutually interact to describe the dynamics of transitions. In the landscape level, elements such as ecological modernization and corporate social responsibility interact with elements of the regime level-legal, technological, and efficiency aspects-and with the niche's aspects, represented by transitions from low to high quality and efficiency in services. This proposed model is justified by the lack of studies that address the sustainability transition models in hospitals and by its potential of adaption to particular contexts.
\end{abstract}

Keywords: business model; innovation; sustainability transition; multiple-level perspective; hospitals

\section{Introduction}

Sustainability imperatives are widespread around several economic sectors and have contributed to the achievement of social welfare, but unlimited economic growth, pursued in business, seems unrealistic [1]. Sustainability is especially important for hospitals, mainly for the fulfillment of social requirements, and to avoid environmental and health risks.

Health services are considered valuable resources that have faced considerable changes over recent decades [2]. These changes involve the management of high costs of development for raising quality standards and for the accomplishment of legal aspects (environmental and social). This scenario poses challenges to current models in health. It requires a new way of thinking strategically to ensure sustainability [3]. The primary external constraint for hospital business is the rapid ageing of the population in unhealthy conditions. It generates medical and related cares [4] that demand rapid capacity of adaption regarding the management systems of the business model [5]. At the same time, innovations and systemic modifications $[4,5]$ are necessary to underpin these changes. 
Business models in the healthcare field help to describe, to analyze, to manage, and to communicate: (i) the value proposition of the hospital for their patients and the other stakeholders; (ii) the ways in which the organization creates and provides this value;and (iii) the economic value required to keep or to regenerate the environmental, technical, and legal capital, jointly with the strategies of their organizational boundaries. The business models address the innovative [6], preventive, and continuous application of strategies that improve the efficiency while reducing the risks to the environment and tosociety [7] to promote economic benefits [8].

Although mosthospitals organize their strategic plans and make them clear, the sustainability goals in these plans are not usually detailed. They hinder the dissemination of how sustainability can be pursued, and they impede these organizations from the adoption of the necessary changes to perform sustainability transitions [9].

Sustainability transitions are changes in socio-technological systems that involve at least three structural levels: the technological niches (micro level) of innovation, the regime space(meso level) where business models are designed and performed, and the wide landscape (macro level) where hard and soft innovations are adopted, tested, accepted, or rejected by society. According to Geels [10], for transitions among socio-technological systems to occur, it is necessary to evaluate them from the Multiple Level Perspective (MLP). These transitions only make sense through the analysis of the relationships among the different social actors within each conceptual level [11].

The MLP proposed and revised by Geels [12] is a contemporary approach to the study of changes in society that result from innovation introduction and development $[13,14]$. Several criticisms have been presented about the ability of the MLP to explain the sustainability transition process in diverse contexts. In particular, the absence of a specific discussion about the hospital context and its business models in the development of a theoretical model should be highlighted [15]. Considering this context, two research questions (RQs) are presented:

RQ1. What is the role of each MLP in the hospital context?

RQ2. How does each MLP promote a vision for sustainability transition?

More generically, this study proposes a model for the MLP promotion as a driver for sustainability transition in the hospital context.

This study has the originality of an MLP proposal as the basis for a new conceptual model. On the one hand, an MLP is seen as an exogenous (internal to the environment) and endogenous (internal to the environment) process of development. From the interactions can emerge the dynamics or the processes of learning and the changes that can have a set of practices or socially accepted rules and, over a certain time, in scenarios of a more global character. Thus, on the one hand, the transition to sustainability is an important and relevant factor under the broad aspect of health context, because the future is as important as possible, and in a broader context, to the very raison d'être of the hospital chain. In addition, there is discussion that a shift to a sustainability situation is not present in any economic plane of any organization, which includes a health area.

The next section introduces the research methods. Section 3 articulates the business model, after a systematic literature review. Section 3.2 presents the innovation perspective for the hospitals. Section 3.3 is dedicated to sustainability transition considerations. Section 4 presents the proposed model: the Healthcare Business Model Innovations for Sustainability Transition. Section 4.3 explains the implication of this research. Finally, Section 5 develops the discussion of the results, conclusions, and recommendations for future research.

\section{Materials and Methods}

This section describes the teaching context, method of data collection, and analysis approach used in work. This research has three distinct phases, being a comprehensive review of the literature on the business model, innovation, a construction of the theoretical framework inthe light of MLP theory and the construction of the framework. 
In the first phase, a literature review on business models, innovation, and sustainability transitions was carried out [16-19] with content relationships. The construction of the theoretical reference was made from searches in databases: Science Direct; Scopus; Scielo; EBSCO; Elsevier; PubMed. The searches occurred from May 2017 until June 2017. First, we determined the temporal range of articles with publications above the year 2000. This period was considered to understand that the surveys conducted in this interval are part of the same environmental, social, economic, and technological environment. However, surveys with relevance (for example, large number of citations) that transposed temporal amplitude were included.

Thus, after analyzing the academic context, the volume of scientific production on themes of business models, innovation, and transitions to sustainability in the hospital chain is still a topic of active research. In a survey of the largest health database, PubMed, only nine articles were published between 1809 and 2017 regarding the terms researched (business models, innovation, and sustainability). Of these, only one mentioned that innovation in business models is a necessary step to ensure the sustainability of health systems, but the focus of the article is on the internal context of care. In contrast, when evaluated under the light of the MLP in this context, no publications were found. This leads to a perception of the lack of more robust research on the relationship between business modeling, innovation, and transitions to sustainability in the light of MLP in the health area.

The following keywords that corresponded to the research themewere searched for in the afore-mentioned databases: Business models; Innovation; Sustainable Innovation; Sustainability; Transition to Sustainability; Hospital organizations; Hospitals; Health area; Multiple-Level Perspective. The search fields were: title; key words; summary of publications. Next, the research was grouped into four categories to assist content analysis: (i) business models and innovation; (ii) innovation as a means of generating sustainability; (iii) analysis of the sustainability context in hospitals; (iv) MLP in hospitals.

In the second phase, after the collection of bibliographical data performed in the previous stage, we sought to deepen the themes covered by the MLP theory, and special attention was given to the literature of the MLP model and its dynamics [10-20]. The construction of this phase of the theoretical reference was made from searches in databases: Science Direct; Scopus; Scielo; EBSCO; Elsevier; PubMed. The searches occurred between July 2017 and June 2017. At this stage, the temporal range of articles was not determined. The content analysis consists of a set of techniques and analysis of communications performed through the interpretation of the readings, interview transcripts, testimonials, and documents [21]. This type of analysis is the research process used in textual analysis and in the qualification of the material used to categorize and tabulate the data obtained [22].

Based on the construction of the theoretical framework and content analysis, a framework and a diagram will be developed for the framework proposal. In this sense, the diagram aims to present the main aspects that represent the relationships of business models, innovation, and transition to sustainability in the hospital chain. The framework of reference has as its function to present the concepts that support the aspects [23] that make up the diagram, together with the respective references. For this, a structure was outlined where the starting point is the reference of business models, innovation management and transition to sustainability in hospital environments.

In the third and final phase, with the collection of bibliographic data, content analysis, reference frameworks and diagrams performed in the previous stage, we tried to build the proposed framework. With this set of information, we seek to evaluate the MLP model and its possible relationships with business models, innovations, and sustainability in the hospital sector. For this, a framework will be elaborated, and the instrument and techniques of data collection will be delineated [23].

The instruments of data collection for exploratory research focus on exploring a set of opinions and representations on the subject to be investigated, i.e., going beyond what is described, and seeking relationships [24]. 


\section{Literature Review}

\subsection{The Overview of the Peculiarities of the Business Models in the Hospital Context}

The business model is fundamental to the economic performance [25] and the hospital context is no different. However, it is a difficult concept to understand. Furthermore, it is not stressed as a debate in either the business oracademic worlds. The seminal paper of Bellman [26] is relevant to the depiction of this topic. According to Markides [19] the expression "business" was earlier cited in the essay "Insurance Research" [25]. Zott et al. [18] emphasized that the expression acquired evidence in the 1990s with the development of information and communication technologies (ICT) and e-business management. Since then, the business model was aimed to describe how organizations capture, create, and deliver value [18]. Every organization has explicitly or implicitly some form of business model [25-28].

With business development, specifically from 1980 to 2009, due to the emergence of new information and communication technologies and with the market expansion, business models became complex, as shown in hospital contexts [29]. Currently, the business model concept no longer refers only to business in the electronic commerce context. Rather, it represents the set of organizational capabilities (managed in the micro level) that enables the creation of value in line with its economic, social, strategic [30], environmental, and innovation/technological objectives [31-33]. Table 1 shows the different visions about the business model concept.

Table 1. The Business Model concepts.

\begin{tabular}{|c|c|}
\hline Authors & Concepts \\
\hline $\begin{array}{l}\text { Shafer et al. [16] } \\
\text { Casadesus-Masanell and } \\
\text { Ricart [17] }\end{array}$ & $\begin{array}{c}\text { The business model is defined as representing the organizational fundamental } \\
\text { strategic choices and logic to create and to capture value from a value network. } \\
\text { The business model is the result of strategies chosen and implemented by } \\
\text { the organization. }\end{array}$ \\
\hline Zott et al. [18] & $\begin{array}{l}\text { The business model is the representation of the content, the structure, and the } \\
\text { governance of transactions designed to create value by exploiting } \\
\text { business opportunities. }\end{array}$ \\
\hline Osterwalder et al. [30] & $\begin{array}{l}\text { The business model is the description of the value offered by the organization for } \\
\text { one or several customer segments as well as the architecture of the organization and } \\
\text { its network of partners for the creation, marketing, and distribution of this value } \\
\text { and its relationship with capital to generate profitable and sustainable revenues. }\end{array}$ \\
\hline Timmers [34] & $\begin{array}{l}\text { The business model can be defined as the structure for the flows of goods, services, } \\
\text { and information, including descriptions: of the various business actors and their } \\
\text { roles, of the potential benefits to the business, and of the sources of resources. }\end{array}$ \\
\hline $\begin{array}{l}\text { Chesbrough and } \\
\text { Rosenbloom [35] }\end{array}$ & $\begin{array}{l}\text { The business model is the mediating construct between technology and economic } \\
\text { value with an underlying cognitive role. }\end{array}$ \\
\hline Zott and Amit [36] & $\begin{array}{c}\text { The business model can be defined as the structure, content, and regulation of the } \\
\text { transactions between the organization and its exchange partners, that is, it } \\
\text { represents the conceptualization of the transactional link pattern between the } \\
\text { organization and its partners. }\end{array}$ \\
\hline Zott and Amit [37] & $\begin{array}{l}\text { The business model can be defined as the structure, content, and management of } \\
\text { transactions between the organization and its partners, defining the resulting links. }\end{array}$ \\
\hline Wikström et al. [38] & $\begin{array}{l}\text { The business model describes the activities of the organization to deliver value to } \\
\text { the customer. }\end{array}$ \\
\hline Amit and Zott [39] & $\begin{array}{l}\text { The business model is the representation of the content, the structure, and the } \\
\text { governance of the organizational transactions to identify business opportunities for } \\
\text { value creation. }\end{array}$ \\
\hline
\end{tabular}

Magretta [28] relatedbusiness models to the logic that enables organizations to earn money. It resembled the theory of Drucker [40], according to which a successful business model should include 
the value offered to the consumer and the skills with which the organization captures the network value. Shafer et al. [16] developed a diagram to identify four categories that influence a business model: the strategic choices, the value creation, the capture of value, and the value network.In a broader sense, a business model refers to strategic choices, sometimes based on the network of the organization, whose dynamics explain the value creation and capture. However, for a more sustainable context, it is necessary to develop models that integrate sustainable innovation at the foundation ofbusiness models.

In hospitals, the business models are ways to improve the business performing under conditions of uncertainty [26]. Hospitals are environments of continuous change [41]. The more relevant technological innovation becomes for positioning the organization in the market, the more the business model arises as relevant as well [18]. Competitive advantage and technology can be considered as crucial links among strategy, organizational processes, and innovation, facilitating communication and knowledge-sharing amongbusiness networks [26].

Several global trends, such as the personalization health of the services (oriented to the patient), the ageing of the population, and the electronic health systems, meanthat such specific business models mustbe very flexible, quickly adapting to the market trends $[6,42,43]$. However, the challenging issue for the development of the business model for hospitalsis not only related to its complex and ever-changing nature [44]. The intense levels of regulation and interactions among networks with diverse actors also pose difficulties to the business model [43]. In most countries, the health system is a national network directly regulated and managed by the government or by governmental organizations [45]. In these circumstances, to have a business model suitable for the hospitals seems extremely critical, since several stakeholders look for the maximum benefit from the model [31].

An in-depth review of the literature of business models for hospitals highlights the work of Janseen and Moors [42], Björkdahl and Holmén [46], Faezipour and Ferreira [47], and Dubosson-Torbay et al. [48]. Janseen and Moors [42] investigated the organizational strategies with a focus on sustainable innovations adopted in the Dutch health area. Björkdahl and Holmén [46] carried out a study to understand the practices of primary care in the Australian health case, focusing on the governance structure in the primary sector of health. Faezipour and Ferreira [47] analyzed the health management problems through a patient satisfaction perspective; they identified essential factors and their causal relations that affect the patient satisfaction and, eventually, the level of social sustainability of the healthcare professional. Dubosson-Torbay et al. [48] proposed a model to implement the management of organizational rules in the health sector tofacilitate the change of process and business practices quickly and efficiently.

These studies deliver many elements that mediated the relationship among the business models, innovation in the hospitals, value proposition, value chain, and strategies. Most authors associate the business models with a static perspective [49]. It means reducing business models to a conceptual tool with its core elements and their interrelationships [17,50]. Thus, the implicit assumption is that the business models remain stable overtime [49]. Besides, market changes can make the prior business models redundant, leading organizations to change their business models [15]. This dynamic vision brings new dimensions to the business model concept.

The static perspective considers a holistic view of the business model [51] through which internal and external sources of value are simultaneously considered [52]. Other static perspectives regarding the business model as an abstraction help the viewer to simplify business complexities, enabling comparisons about business costs $[15,53]$. The literature review performed by Lambert and Davidson [54] reinforced this idea and suggested that a business model can be seen as a strategic analysis tool. The mapping of a focal business model can be used to analyze and to communicate strategic choices and, therefore, to define how an organization can create value and how it will be captured as an advantage from internal sources [54]. In the static perspective, the focal subject does not need to be a company. It can also be a system, a business unit, or a product $[52,53]$.

The dynamic perspective essentially adds the time flow to the concept, thereby making the business model subject to change [53]. In this sense, the changes that occur in different parts of the 
business model must be aligned with the long-term strategy, considering the culture and the basic skills. The business model also provides an integrated view of the focal company and of the interrelationship among the different activities of the organization [52]. Also, new business models not only represent innovation, but also facilitate it [25]. A dynamic perspective contributes to the development of the economic value of technology through business models. It emphasizes the role of the value creation and, thus, the capture of value [55]. Lüdeke-Freund [56] advocated that a business model is a mediator that makes the difference between the business case for innovation and sustainability.

\subsection{Innovation under the Perspective of Business Models in the Hospital Context}

The concept of innovation datesback to the publication of the work of Schumpeter [57] entitled "The Theory of Economic Development". According to Schumpeter [58], economic development is driven by innovation through a dynamic process in which new technologies replace old ones, known as "creative destruction", and later it was expanded by the Neo-Schumpeterian vision to take account of social scope. Table 2 shows the different visions ofthe innovation concept.

Table 2. The Innovation concepts.

\begin{tabular}{|c|c|}
\hline Authors & Concept \\
\hline Schumpeter [57] & $\begin{array}{l}\text { Innovation is defined as a process characterized by the description of the present, } \\
\text { termed and "creative destruction",conceived through the introduction of a new } \\
\text { good or new quality of a good, a new production booth, the opening of a new } \\
\text { market, the conquest of a new source of raw material, or still the creation of a new } \\
\text { form of organization. }\end{array}$ \\
\hline Hekkert and Negro [59] & $\begin{array}{l}\text { Innovations in the organization are changes that impact the behavior of economic } \\
\text { actors, whether at its external level (national, regional, and sectoral) or } \\
\text { internal level. }\end{array}$ \\
\hline Freeman and Perez [60] & $\begin{array}{l}\text { Innovation can be distinguished in categories in terms of the intensity of the } \\
\text { modification in the organization. The importance of innovation raises questions } \\
\text { about the ways of structuring the organization for innovation. }\end{array}$ \\
\hline Fussler and James [61] & $\begin{array}{l}\text { Innovation is qualified as one of the five competitive criteria of the organization, } \\
\text { which are aligned and integrated with generic competitive strategies. }\end{array}$ \\
\hline OECD [62] & $\begin{array}{l}\text { Innovation is the implementation of a new or significantly improved product, } \\
\text { process, marketing method, or organizational method in practices, business, } \\
\text { workplace organization, or external relations. }\end{array}$ \\
\hline Christensen et al. [63] & $\begin{array}{l}\text { Innovation can be disruptive that means the rupture of an old business model } \\
\text { that changes the bases of competition. It aims to give rise to new markets and new } \\
\text { business models by presenting more efficient solutions than the existing ones. }\end{array}$ \\
\hline Balan and Lindsay [64] & $\begin{array}{l}\text { Innovation process requires specific conditions. The conditions are related to the } \\
\text { ability to mobilize and to manage resources and routines to develop and to } \\
\text { introduce of new products and services. }\end{array}$ \\
\hline Tidd et al. [65] & $\begin{array}{l}\text { Innovation is a consequence of organizational processes aligned with the } \\
\text { organizational strategies that generate projects for competitive advantage. }\end{array}$ \\
\hline Gallouj and Savona [66] & $\begin{array}{l}\text { Innovation capacity is the ability of the organization to generate value to the } \\
\text { customer through the development and introduction of new products and } \\
\text { services or the reduction of costs induced by the process of value creation. }\end{array}$ \\
\hline Gunday et al. [67] & $\begin{array}{l}\text { Innovation is considered to be evolution and new applications, with the aim of } \\
\text { launching the novelty for the market. Innovation is of great commercial } \\
\text { importance, because of its potential to increase the efficiency and profitability of } \\
\text { the organization. Therefore, innovation plays a significant role in creating } \\
\text { differences performance and competition between organizations, regions, and } \\
\text { even countries. }\end{array}$ \\
\hline
\end{tabular}


Hekkert and Negro [59] defined the term innovation as a process of translating ideas into products, services, or processes that are useable and useful. Innovation has two categories: incremental or radical. Incremental innovation generates small improvements in existing goods, services, or processes, improving a way of doing something that was previously done. Radical innovation engenders more intense ruptures, causing a profound change in goods, services, or processes.

In hospital institutions, changes and novelties are part of routines, and hospitals around the world have devoted attention and resources to innovation [68]. However, the present authors have highlighted the lack of knowledge about innovation in hospital institutions. Innovation in the hospital context represents a competitive advantage mainly in the management of new business models. The ability to innovate promotes a transition, i.e., a change in the way hospitals adapt to new environmental, social, and economic needs in an increasingly dynamic and global world [68-70].

Following the idea of the transition, according to Schumpeter [58], innovation is based on five assumptions: the introduction to the market of a new good or service; the introduction of a new method of production; the creation of a new market in a given country; the achievement of a new source for supply of raw materials or semi-manufactured products; and the deployment of a new structure in a market, in which everyone can link to business models.Following the Oslo Guideline [71], every innovation needs to contain some degree of novelty. In this sense, there are three levels for the innovation novelty or transition: new to the company, new to the market, and new to the world. The first occurs when an individual company introduces a novelty in itself (in the business model-micro level). In turn, the innovation to the market consists in the introduction of this one by a particular company in its market (meso level). Innovations for the world are those in which a company is the first to introduce it at all, in a domestic or international market. In this way, the degree of novelty of an innovation to the world (macro level) is higher than that with an emphasis on the market [71].

Davila et al. [72] exposed the distinction among the types of innovation in their intermediate stage, i.e., meso level. The authors analyzed the innovation perspectives within the corporate context, observing that not all innovations are introduced in the same way, presented the same risks, generated the same returns. The types of innovation related by Davila et al. [72] represented a significant change that affects both the business model of an organization and its technology.

The business models of hospital institutions are constantly under pressure, which stems from the increase of population, new diseases, the search for higher-quality services, technological innovations, changes in local laws, and changes in competitive positions of players [73]. Djellal and Gallouj [74] stated that hospitals are considered to be a nodal point of the healthcare system in relation to the several actors within this system: an industry of medical-hospital equipment, pharmaceutical industry, health insurance, public health policies, health professionals, among others. These relationships promote the exchange of knowledge and information among these actors, which contribute to the development of innovations. Also, hospitals are centers of teaching and research in diverse areas, which put them closer to the scientific and technological development.

The process of innovation provides "new combinations" of resource and equipment [57] and the business models have the role of identifying the form in which hospitals present the value proposition to their customers and create and capture the economic value [75]. In this way, the innovation of business models consists in managing this process of innovating (new transitions), in how the organization interacts with all "stakeholders", i.e., how the organization creates, delivers, and obtains value [51].

As a starting point, the innovation of hospital business models may have different motivations: "to have a crisis existing with them (reactive); to adjust, to improve, or to defend the existing models to adapt them to a changing environment (adaptive); to bring new technologies, goods, or services to the market (expansive); to prepare for the future, exploring and testing completely new business models that may eventually replace the existing ones (proactive/exploratory/)" ([51], p. 278).

Windrum and Koch [76] argued that hospitals are centers of transition of technological innovations developed in the industry of medical-hospital equipment and the pharmaceutical industry. For this 
reason, hospitals have relations with these suppliers, especially under two aspects: (i) incorporation of innovations developed by them, thereby participating in the process of diffusion of these novelties; and (ii) participation in the process of research and development by the development of research projects in partnership.

In this sense, Anatole-Touzet and Souffir [77] emphasized that hospitals are real innovation systems. According to these authors, four types of innovation occur in hospital environments:

(i) organizational innovations (micro level) refer to the organizational structure in a general way, e.g., the implementation of quality control, work organization, and treatment protocols;

(ii) service innovations (micro level) refer to changes in the way hospitals provide services to customers, e.g., the creation of support services to families of chronic diseases such as cancer and HIV-related diseases;

(iii) technological innovations (meso level) refer to the adoption of all kinds of technologies, as equipment, materials, information systems, and biotechnology; and

(iv) the social and cultural innovations (macro level) refer to culture and the sociology of work in hospitals, such as the development of training programs based on the solution of problems and the improvements in working conditions.

\subsection{Sustainability Transitions}

In the past 50 years, the transition concept has become highly relevant in areas of knowledge such as political science, social science, and the environment, prompting the advent of a new era called "transitology" [78]. The transition concept was used by researchers in 1980s for sociotechnical studies relating to environmental issues, due to the attention paid by the World Commission on Environment and Development, which earlier introduced the concept of "sustainable development", defined as "development that meets the needs of the present without compromising the ability of future generations to meet their own needs" [79].

This new approach has caught the attention of new interests that aim to investigate transitions to a sustainable economy. In the transition concept context, the proposals of sociotechnical research involve changes of limited range within society or essential subsystems [20]. In this sense, the transition idea was reassessed. Loorbach and Rotmans [80] analyzed the need for fundamental changes that have happened in structures (for example, organizations and institutions), in culture (for example, standards and behavior), and in practices (for example, routines and skills), for the assessment of sustainable development, i.e., transitions for future sustainability. Topics such as sustainability transition, sustainable innovations, sustainable business models, and the advent of sustainable technologies have achieved prominence in recent decades, as several concepts have advanced for the analysis of these new approaches [81].

According to Smith et al. [82], transition involves a wide range of changes in different dimensions (technological, organizational, institutional, material, political, economic, and sociocultural) which create the settings required for the construction of the contexts that can be modified. In this sense, according to Meadowcroft [83], sociotechnical settings in specific systems for change are established as the dominant and stable way to accomplish a social function. This concept facilitates the understanding of sustainability transitions within the logic of systemic changes from a continuous process [12]. According to this author, these changes are aligned with transformation systems.

These systems are part of multi-action actors, who are involved in the MLP. The MLP considers the accomplishment of changes in accordance with dynamics in society, which are settled in micro (the sociotechnical niches level, which are new configurations); meso (which change the sociotechnical regimes—such as rules); and macro scales (where there is a large sociotechnical involvement-defined as "landscapes"level) $[10,12,83]$. Among these different scales of the MLP, interactions among different actors take place for the search of a better context of change in society $[10,84,85]$. There 
is a complementarity among diverse types of transitions regarding depth and it differentiates the impact of change movements in the different levels.

\subsection{The Multiple-Level Perspective}

Inherent to the proposition of Geels [84] is the understanding of transitions among socio-technological systems from the MLP. It embraces the study of transition from three interrelated levels of analysis: niche, regime, and landscape. From this perspective, it is understood that innovations emerge and are usually developed in the niche level—micro level—characterized by a company or a group of interrelated companies which has correspondence with the dynamics of the landscape, the technological regimes, and the niches of innovation $[10,86,87]$, the three MLP levels.

The landscape (macro) refers to a global sociotechnical definition, which covers both the intangible aspects of social values, opinions, and political and the tangible aspects, involving institutions and the market functions, such as prices, costs, standers, and income. Therefore, it represents the set of elements that have significant impact in the other two levels.

The regime (meso) refers to the dominant practices, procedures, and technologies that provide stability and strength to the prevailing sociotechnical systems [11]. The sociotechnical scheme involves three interdependent elements: (i) the network of actors and social groups that adapt overtime to the dynamics of the system; (ii) the set of formal and informal rules that address the behaviors and actions of the actors to protect and to guide the nature of the sociotechnical system; and (iii) the set of materials and technological components.

The niche (micro) refers to a protected space, i.e., in particular, environments in which radical innovations can mature and be protected from these elective pressures of the main sociotechnical regime [88].

The MLP is a theoretical approach that is valuable for describing a real transition prospectto address the study of patterns, causes, and impacts of different phenomena in transition processes [84-87]. With an MLP perspective in Figure 1, the search for new transition elements departs from the construction of innovation and networks of actors, with all related aspects focused on a common goal.

\section{Increasing structuration of activities in local practices}

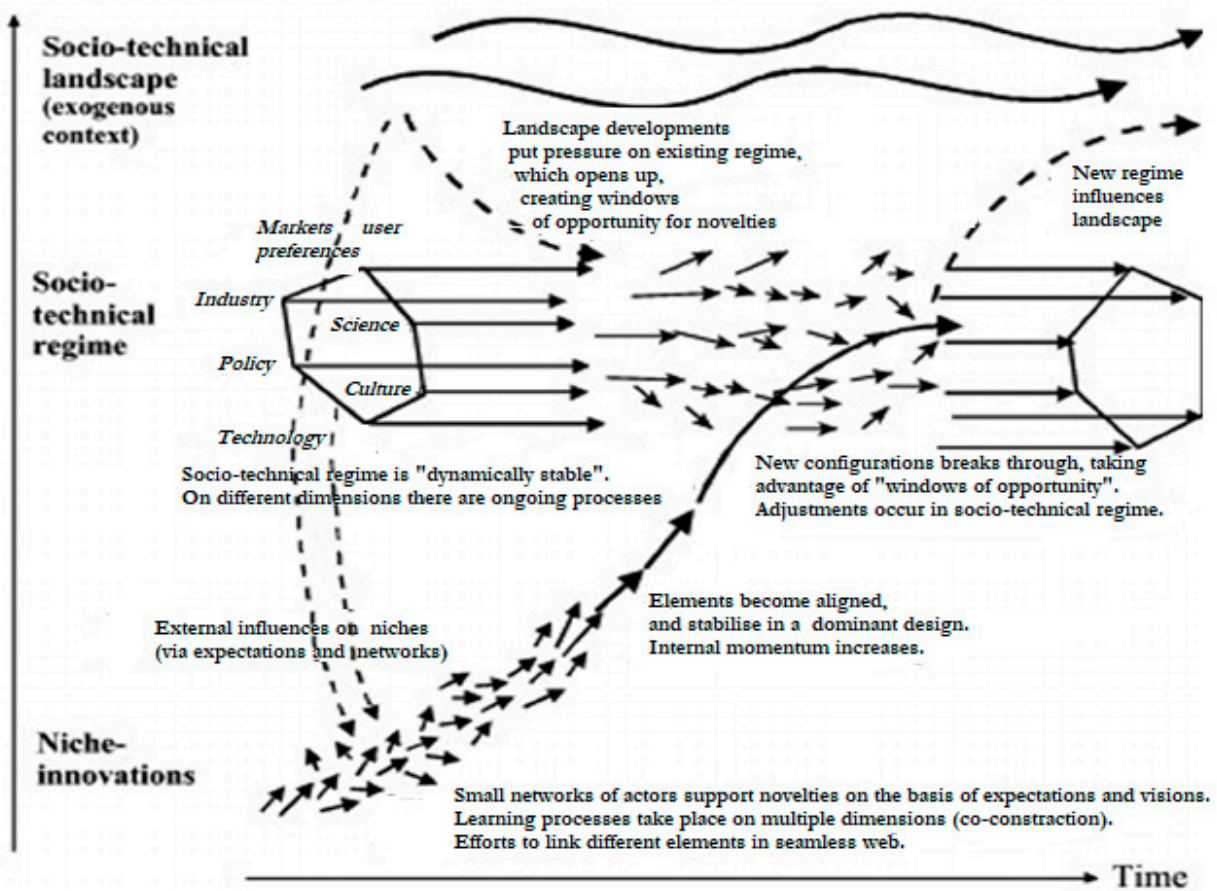

Figure 1. The Multiple-Level Perspective by Geels [10]. 
The involvement required among diverse sets of fields of influence is highlighted. They evolve together overtime to deliver macroeconomic stability of the context. Sustainability transitions are long-term and multidimensional and assume a pivotal changing process for the establishment of sociotechnical systems that seek sustainable ways of production and consumption [88,89].

In the transition movement, the need for interactions among the elements, such aseconomy/business/market, technology, politics/power, and culture /speech/public opinion, is essential for the effectiveness of the perspective [84]. Despite this notion, Smith et al. [82] and Geels [12] considered that there is criticism for the approach in several aspects: the role of the agency for transitions, the power relations in the regimes (mainly in the niches), and the difficulty of operationalizing, especially when analyzed the hospital context.

\section{Results}

\subsection{The Healthcare Business Model Innovations for Sustainability Transition}

The basic design of health systems and subsequently the structuring of the hospital as an organization of specialized healthcare took place between the end of the 19th century and the beginning of the 20th century. Both the health system and hospitals went through many transitions. However, all transitions have been natural or incremental improvements.

Hospitals are recognized as complex organizations due to the different exchanges among actors that interact with hospital systems: suppliers, legal regulators, health medical plans, and patients. Many times, this interactivity among actors cannot establish equitable gains, i.e., the different needs of each actor have consequences for the hospital business model and even for the development of sustainability as a whole. In this gap, the MLP is introduced in the hospital context and it provides an analysis of how the transition process is not linear. It is observed that the interaction of developments is generated in three analytical levels (RQ1): niches (the locus of the business model), regimes (the locus of established practices and associated rules that stabilize the existing systems through innovation), and an external socioeconomic situation, which is the landscape [10]. As a contribution of this model, it was added a view of the levels, with the integration of the internal environment (niches and regimes) with the external environment (landscape). Each level refers to a different configuration of elements. The highest level (landscape) is more stable than the lowest regarding several actors and degrees of alignment among the elements.

However, to reach the multilevel landscape, one must structure the business models of each actor in the health chain for this vision. In this sense, the role (RQ1) the business models (multilevel niche) must be supported by well-structured strategies and technological, service, organizational, social, and cultural multilevel regimes, extending to a multilevel landscape vision. The multilevel landscape aims to generate actions for the chain of actors, through business partnerships, governance, and social responsibility, that generate social actions, ecological, and sustainability of service. Nevertheless, only with the maturation of the set of actions at all multilevel is it possible to achieve the sustainability transition.

Therefore, hospitals require business models driven by innovation, which aim to create a sustainability transition to support the increase of demand, assuring the needs of future generations. The model for sustainability transition (RQ2) level for hospitals should not include only the issues of new technologies, practices (clinics), or management. It should cover business models addressed to promote sustainability [33]; Table 3 shows the interaction between the business model and sustainability transition. One of the main challenges in hospitals is to ensure the success of a business model with a larger scope, i.e., in adynamic landscape where economic results are comprehensive, and they stimulated several benefits: environmental, social, economic, legal, quality, strategic, and technological. 
Table 3. Summary of the interaction between Business Model and Sustainability Transition.

\begin{tabular}{|c|c|c|}
\hline & Business Model & Sustainability Transition \\
\hline Concept & $\begin{array}{l}\text { The business model refers to the } \\
\text { description of the value offered by the } \\
\text { organization to its clients, as well as the } \\
\text { architecture of the organization in relation } \\
\text { to its network of partners for the creation, } \\
\text { commercialization, and distribution of } \\
\text { this value and its relationship with capital, } \\
\text { to generate revenues profitable } \\
\text { and sustainable }\end{array}$ & $\begin{array}{l}\text { Sustainability transition involves a range of } \\
\text { changes in different dimensions: } \\
\text { technological, organizational, market, } \\
\text { institutional, material, political, economic, } \\
\text { and sociocultural, which create the necessary } \\
\text { configurations for the construction of contexts } \\
\text { that can be modified }\end{array}$ \\
\hline Key issues & $\begin{array}{l}\text { * Lack of vision of organizations } \\
\text { * Innovation is a driver of improvement } \\
\text { * Positive impacts in the internal and } \\
\text { external context } \\
\text { * The doubt about whether the } \\
\text { organizations are prepared to generate } \\
\text { business models with a vision } \\
\text { for sustainability }\end{array}$ & $\begin{array}{c}\text { * Lack of vision of organizations } \\
\text { * Innovation promotes } \\
\text { sustainability transition } \\
* \text { Results are always collective } \\
* \text { The doubt about the issues for the } \\
\text { organizations and society to further develop } \\
\text { sustainability transition actions }\end{array}$ \\
\hline Wide scope & Internal and external contexts & Internal and external contexts \\
\hline Focus & $\begin{array}{c}\text { Oriented to the business market, mainly } \\
\text { in the exchanges between the parties of } \\
\text { the supply chain }\end{array}$ & $\begin{array}{l}\text { Aimed to the development of strategies for } \\
\text { sociotechnical and sociocultural actions that } \\
\text { promotes future sustainability }\end{array}$ \\
\hline
\end{tabular}

According to Kaissi et al. [90] business models are deeply related to the value concept in most hospital business models. The value of the business models for Osterwalder and Pigneur [51], and for Teece [25], strongly relied on the benefits of topics such as organizational management, profit, image, participation in the market, and customer satisfaction in the form of quality, health, and safety. According to Christensen et al. [43] there were further benefits, i.e., by means of innovation, improved business models can generate other results which generate gains for the whole collective [91].

In the hospital context, sustainability is a sensitive he same level in the health field. For this reason, it is desirable that, in addition to hospitals, the whole chain of related actors guide business models through innovation. It improves the possibilities of success in a sustainability transition direction, creating opportunities such as cost reduction, environmental impact monitoring, quality improvement, strategic gains, fulfillment of the legal requirements, efficiency in processes, and new technologies [59,92].

The exploration of the concepts relating to business models for innovation in the hospital context provided subsidies for the design of the proposed model. In this sense, to approach, since it is difficult to relate the environmental, social, and economic dimensions to the goal was to characterize the aspects present in the hospital sector, covering the external environment and considering the main actors that have influence in the processes of hospital business models: (i) suppliers; (ii) legal regulators; (iii) health plans; and (iv) patients.

The main objective of the proposed model (Figure 2) is to depict the elements in which hospitals are inserted, resulting from the approach of business models, innovation, and sustainability transition. 


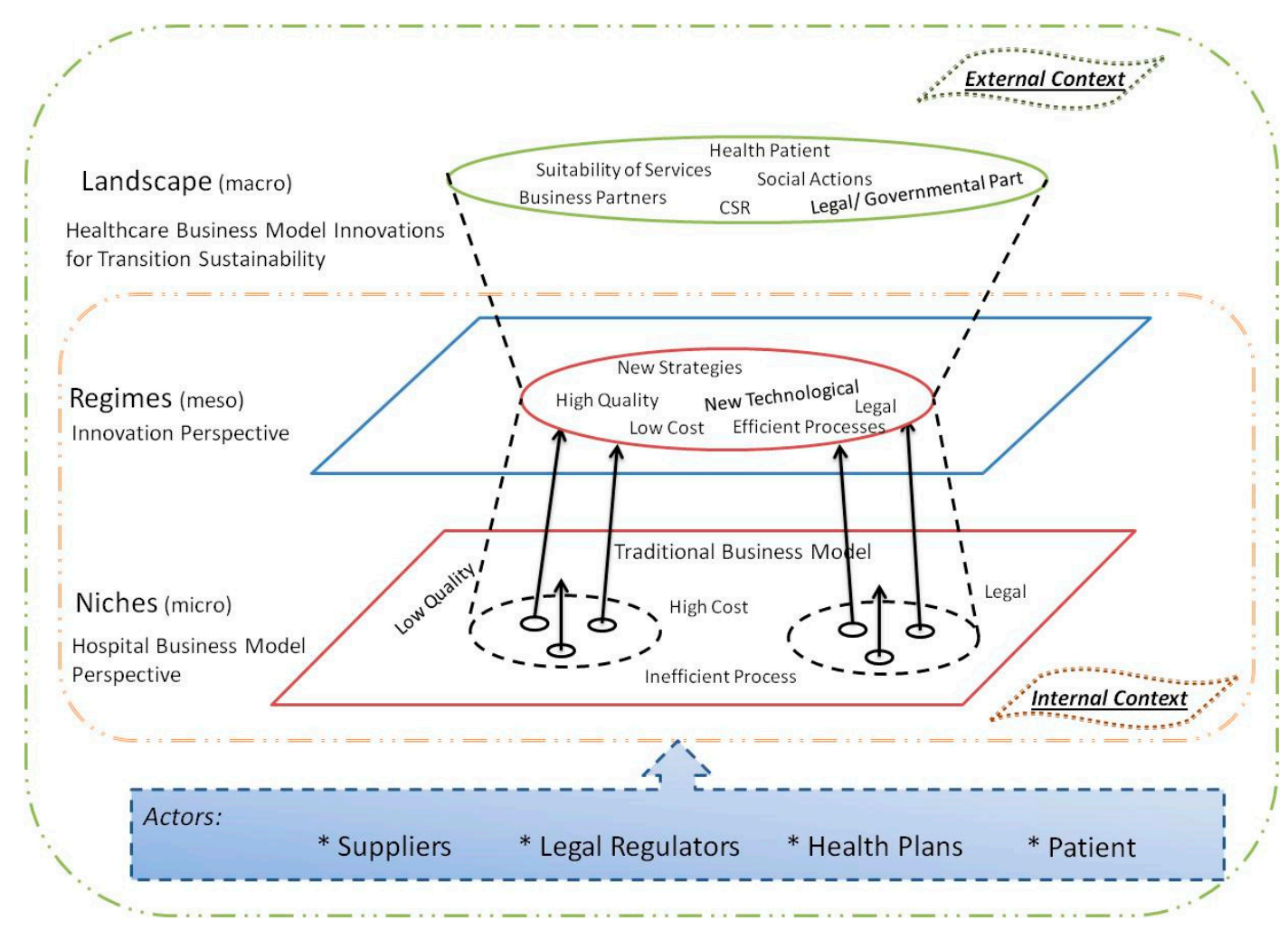

Figure 2. The Healthcare Business Model Innovations for Sustainability Transition.

For the implementation of this model it is necessary to idealize in the hospital chain:

- Awareness-generate awareness of the chain in general for the need for actions to change sustainability;

- Culture of sustainable business models—create a centralized chain of business model development aimed at sustainability, and stimulate a chain for the sustainability of business models oriented towards updating actions for sustainability;

- Management of the initiative-create a new initiative, disseminate information on ongoing actions, keep informed, and inform the list of signatories;

- Innovation Management-develop management of ideas and innovations of the chain. It is treated in a systematic way, encompassing the strategy, resources, governance, organizational models, processes, and tools geared to a generation of organizational culture conducive to innovation;

- Involvement of external actors-Engage all actors, encourage the participation of industries, actions, and other forms of support.

With the basic idea related to a change in the performance of different actors focused on the search for a harmonization between social, economic, and environmental aspects, the transition to sustainability has an inter and intra organizational concern [79]. According to Farla et al. [89], the transition to sustainability involves a range of changes in different dimensions: technological, organizational, institutional, material, political, economic, and sociocultural, which create the necessary configurations for the construction contexts that can be modified.

\subsection{Discussion}

The sustainability transition discussion under the MLP approach points out the actions that must be carried out by different actors (hospitals, suppliers, legal regulators, health plans, and patients) in the search of new sociotechnical configurations that impact the environment and society in different ways [93]. It should be emphasized that all sustainability transition discussions are based on innovation, 
which relates to business models. By evolution among levels, it is possible to have a successful transition in the level of niche, to proceed to the regime level, and to reach the landscape level. However, while creating a new landscape level, it is possible to build long-lasting sociotechnical regimes aligned with the transition process, where the environment, society, and the organizations have a more significant outcome based on sustainability.

Within the transition context, different trends of change can take place in the context of business andsociety with social actions, adequacy of services, legal/governmental part, corporate social responsibility (CSR), business partners, and the principle the health patient [12]. The MLP perspective can be developed as a basis for solutions in the chain from the building of business models based on innovations among actors. These transformations can take environmental, social, cultural, and business levels not covered before and they can have a direct impact on how businesses are treated in the hospital context, in the health chain. Nevertheless, it is necessary to understand the involvement of the diverse actors and the transition [84].

As already discussed, at each transition loop, the niche, the regime, and the landscape levels in the sociotechnical structures of hospitals should consider the current systems in transition context. In this case, the rules of change can be more developed than in the created landscape context. The MLP assesses the hierarchy where there is the search of continuity within changes in the stable perspective. It leads to a field where rules can change, but the contexts between the levels are left unchanged. In this sense, according to Smith et al. [82], sociotechnical configurations in specific regimes for change are established as the dominant and stable ways to accomplish a social function.

This concept facilitates the understanding of sustainability transition within the logic of systemic changes from a continuous process [84]. As an example, in Brazil there is a movement between hospitals and health plans with more beginner systemic changes mainly among actors. The transition from a traditional business model to an integrated vision of hospital or in cooperation with the whole set of stakeholders is a critical trend in a context where the health systems must ensure sustainability of services to society. Therefore, hospitals must adapt to the new needs of the patients, as well as new forms of business models employing innovation, which will help to expand the gains for the chain of actors involved in the hospital area.

\subsection{Implication}

This research sought to contribute to the lack of theoretical contextualization of an MLP within the field of sustainability transition, conceptualizing business models as a potential source of change and inertia within hospital sociotechnical systems through innovation. For this, it proposes a model for the promotion of the MLP as a driver for sustainability transition in the hospital context.

The business models can have static and dynamic views within the hospital context. The static view of business models can be used to create micro-level descriptions and typologies that encompass organizations and their value networks. It also elucidates the way in which established business models act as a source of inertia within sociotechnical systems. The dynamic view, on the other hand, sees business models and innovation as separate and distinct processes. However, it can potentially function as a central axis for co-evolutionary processes.

The model was based on the MLP to derive a set of propositions that may form the basis for future research in the sustainability transition field. The MLP has the potential to transform the hospital chain radically and to direct it towards a more sustainable path. However, the nature of the hospital chain is so complex that its sustainability transition is based on significant changes in business models, which in turn are heavily influenced by innovation.

Therefore, the business models face two significant challenges: to overcome significant barriers of lack of connection between the chain business models and to contribute to the creation of visions and expectations that can motivate a diverse set of key stakeholders as part of strategies. By combining business model ideas, innovation, and sustainability transition (Figure 3), new research can help the transformation process by providing key stakeholders with the knowledge and resources they need 
as part of the action research agenda. In the construction of movements for transition, the need for interactions among the actors of the chain is noticeable, so that the MLP can be realized. There are still many issues to understand better about the MLP, such as the role of each actor for the transitions, the power relations between actors at each multilevel, and the difficulty of operationalization. There is a need for follow-up studies in this field.

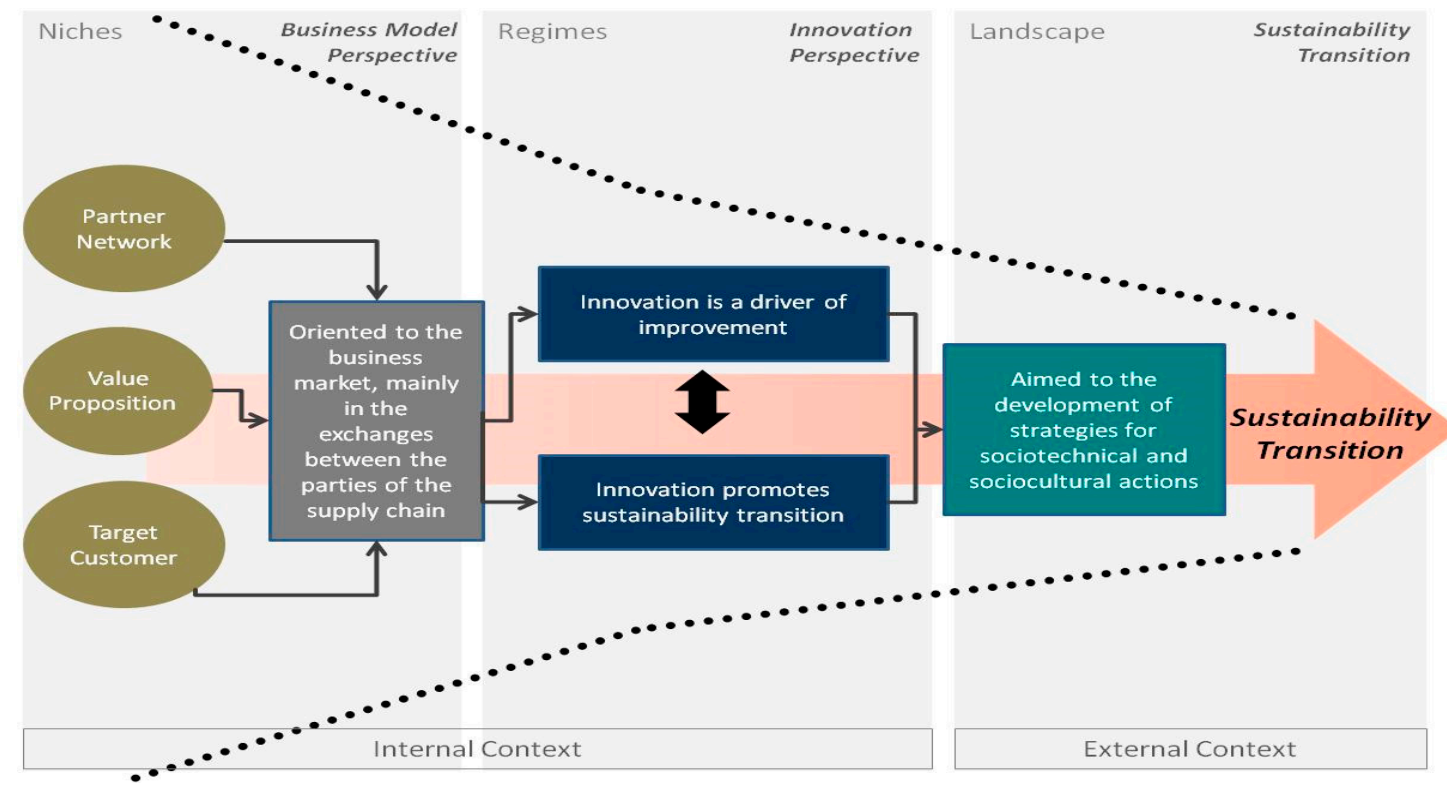

Figure 3. The MLP for a business model, innovation, and sustainability transition.

This research represents a broad effort of conceptual construction. It addresses the concepts of business models and innovation that might contribute to the sustainability transition movement once new sociotechnical systems get space in these organizations. The main limitation is the lack of understanding of the perceptions of the actors (supplier, legal regulators, health plans, and patient) in the hospital context about the sustainability transition concept. Interviews or surveys could help this research to evaluate these perceptions. Future research studies could interview and survey these actors in hospitals context.

The proposed model can be adapted to many other contexts to promote the MLP as a driver for sustainability transition. In other words, the proposed business model has significant potential to form the basis of analysis within the niche level that could, together with the innovation regime, promote sustainability transition in the landscape level.

\section{Conclusions}

This study underscored the need for an evolution in business models through innovation for sustainability transition in the hospital context and its chain of actors. This vision aligns to the guideline of the hospitals to ensure the success of their business models through innovation, balancing competitiveness, and value delivery to the population [42,43]. Thus, solutions should not only include some actors or levels in new technologies, practices (clinicians), or management, but rather all the actors linked by business models driven by innovation to provide gains in the sustainability dimensions.

The option for this theory finds funding in MLP surveys as in studies by Smith and Raven [94] and Martin [95]. These studies of framing business models as a sociotechnical niche, and of innovation at the regime level, can influence and modify the most comprehensive systems, whether atthe niche level, the regime, or the sociotechnical scenario [10,32,81].

The WHO [2] also highlighted the possibility of reducing relations between the different actors in the health context, improving the quality of services, innovation and technology, or financial 
sustainability of the chain. This vision is aligned with the hospital chain, guaranteeing the success of its business models [2-12], balancing the potential and delivering value to the population [35].

Thus, as solutions can be applied, some new functions such as technologies, practices (management) [36,39-42], but rather of actors linked in a chain as innovation-driven business models [42-45], for perhaps the gain also in the dimensions of sustainability. Analyzed by means of a chain view, an offer that can be useful in relation to an environmental, social, and economic perspective, and in strategic dimensions, such as quality, legal and technological, is presented in the Tables 1 and 2.

Hospitals need to meet governmental regulations and to provide better services to patients and competitiveness in the health field (partnerships and health plans in the private sector as pivotal actors). They also need to control costs, and to sustain the rising of new technologies in a sophisticated context. In particular, under the appearance of a chain, hospitals need to develop capabilities for managing the business needs, to understand the relationship between different actors (external and internal), and to establish the decision-making processes [18].

This research discusses the issues resulting from business models, innovation, and sustainability transition from the hospital vision and it proposes a model for the promotion of the MLP as a driver for sustainability transition in the hospital context. The proposed model aims to discuss the issues resulting from business models, innovation, and sustainability transition in the hospital perspective to highlight the elements on which hospitals depend to minimize the gap in the literature on this topic. According to Geels [12], sustainability transition is as a vibrant and challenging issue and it allows supporting dialog within several transitional instances. It should be emphasized that the discussion did not intend to carry out a comprehensive deepening of themes, but rather to demonstrate that relations can be established and better observed in asocial context. From the whole discussion, it is understood that this research has met its proposed objective, as it addressed the evolution of the concepts of business models and innovation that may contribute to the sustainability transition movement. Construction of a new sociotechnical regime, applied to the hospital context as well, enables stability in the dynamics of change.

However, there is a broad field of discussion surrounding transition. The focus of this research study was the MLP, which was considered as motivation, and that explained relationships for a set of actions in the hospital context [93]. It is expected that the proposed model contributes to further discussions within this theme in the hospital context. It should be noted that this research is the first that presents a model of a business model, innovation, and the MLP in the hospital context. Future research could evaluate the influences between the internal and external contexts and the influences between actors and levels of the MLP in the hospital context. Finally, it is suggested that further investigation discusses the possible outcomes in sustainability transition for healthcare organizations based on their business models and the adoption of innovations.

Author Contributions: Writing, C.M.L.; Providing case and idea: C.M.L., A.J.S.; Providing revised advice: G.L.R.V., C.R.P. and A.L.K.

Funding: This research received no external funding.

Conflicts of Interest: The authors declare no conflict of interest.

\section{References}

1. Buys, L.; Mengersen, K.; Johnson, S.; Buuren, N.V.; Chauvin, A. Creating a Sustainability Scorecard as a predictive tool for measuring the complex social, economic and environmental impacts of industries, a case study: Assessing the viability and sustainability of the dairy industry. J. Environ. Manag. 2014, 133, 184-192. [CrossRef]

2. World Health Organization (WHO). World Health Statistics 2015; World Health Organization: Geneva, Switzerland, 2015.

3. Unger, S.; Landis, A. Assessing the environmental, human health, and economic impacts of reprocessed medical devices in a Phoenix hospital's supply chain. J. Clean. Prod. 2016, 112, 1995-2003. [CrossRef] 
4. Organisation for Economic Co-operation and Development (OECD). Towards Green Growth-A Summary for Policy Makers; Organization for Economic Cooperation and Development: Paris, France, 2011.

5. Brooks, P.; El-Gayar, O.; Sarnikar, S. A framework for developing a domain specific business intelligence maturity model: Application to healthcare. Int. J. Inf. Manag. 2015, 35, 337-345. [CrossRef]

6. Bohrer, C.T.; Vargas, E.R. Innovation in hospital services from a perspective of technical operations: Case studies in university hospitals. In Proceedings of the 7th International Conference on Innovation and Management, Wuhan, China, 4-5 December 2010.

7. United Nations Environment Programme (UNEP). Towards a Green Economy: Pathways to Sustainable Development and Poverty Eradication. 2011. Available online: http://wedocs.unep.org/handle/20.500. 11822/18966 (accessed on 23 May 2017).

8. Birkin, F.; Cashman, A.; Koh, S.C.L.; Liu, Z. New sustainable business models in China. Bus. Strategy Environ. 2009, 18, 64-77. [CrossRef]

9. Loorbach, D.; Wijsman, K. Business transition management: Exploring a new role for business in sustainability transitions. J. Clean. Prod. 2013, 45, 20-28. [CrossRef]

10. Geels, F.W. Technological transitions as evolutionary reconfiguration processes: A multi-level perspective and a case-study. Res. Policy. 2002, 31, 1257-1274. [CrossRef]

11. Geels, F.W. From sectoral systems of innovation to socio-technical systems: Insights about dynamics and change from sociology and institutional theory. Res. Policy. 2004, 33, 897-920. [CrossRef]

12. Geels, F.W. Ontologies, socio-technical transitions (to sustainability), and the multi-level perspective. Res. Policy. 2010, 39, 495-510. [CrossRef]

13. Jackson, T. Prosperity without Growth? The Transition to a Sustainable Economy. 2009. Available online: https: / / research-repository.st-andrews.ac.uk/handle/10023/2165 (accessed on 18 June 2017).

14. Sarasini, S.; Langeland, O. Integrating a business model perspective into sustainability transitions: A research agenda based on servitised mobility. In Proceedings of the 7th International Sustainability Transitions (IST) Conference, Wuppertal, Germany, 6-9 September 2016.

15. Boons, F.; Lüdeke-Freund, F. Business models for sustainable innovation: State-of-the-art and steps towards a research agenda. J. Clean. Prod. 2013, 45, 9-19. [CrossRef]

16. Shafer, S.M.; Smith, H.J.; Linder, J.C. The power of business models. Bus. Horizons. 2005, 48, $199-207$. [CrossRef]

17. Casadesus-Masanell, R.; Ricart, J.E. From Strategy to Business Models and onto Tactics. Long Range Plan. 2010, 43, 195-215. [CrossRef]

18. Zott, C.; Amit, R.; Massa, L. The Business Model: Theoretical Roots, Recent Developments, and Future Research. Manag. 2010, 37, 1019-1042.

19. Markides, C.C. Business model innovation: What can the ambidexterity literature teach us? Acad. Manag. Perspect. 2013, 27, 313-323. [CrossRef]

20. Rotmans, J.; Kemp, R.; van Asselt, M. More evolution than revolution: Transition management in public policy. Foresight 2001, 3, 15-31. [CrossRef]

21. Liamputtong, P. Qualitative Research Methods; Oxford University Press: Melbourne, Australia, 2013.

22. Yin, R.K. Case Study Research: Design and Methods; Sage Publications: Thousand Oaks, CA, USA, 2013.

23. Flick, U. Qualitative Evaluationsforschung: Konzepte, Methoden, Umsetzungen; Rowohlt: Reinbekbei Hamburg, Germany, 2006.

24. Creswell, J.W.; Clark, V.L. Designing and Conducting Mixed Methods Research; Sage Publications: Thousand Oaks, CA, USA, 2017.

25. Teece, D.J. Business Models, Business Strategy and Innovation. Long Range Plan. 2010, 43, 172-194. [CrossRef]

26. Bellman, R. A Markovian decision process. J. Math. Mech. 1957, 6, 679-684. [CrossRef]

27. Osterwalder, A. The Business Model Ontology-A Proposition in a Design Science Approach Business. 2004. Available online: https://s3.amazonaws.com/academia.edu.documents/30373644/thebusinessmodel-ontology.pdf?AWSAccessKeyId=AKIAIWOWYYGZ2Y53UL3A\&Expires=1545115740\&Signature= 3kir7CpU19c\%2FgEWQdClAAgF41Q8\%3D\&response-content-disposition=inline \%3B\%20filename \% 3DThe_Business_Model_Ontology_a_propositio.pdf (accessed on 3 April 2018).

28. Magretta, J. Why Business Models Matter. 2002. Available online: http://designblog.uniandes.edu.co/ blogs/dise2102pc/files/2013/08/Why_Business_Models_Matter2.pdf (accessed on 30 May 2017). 
29. Nelson, M.L.; Sen, R. Business rules management in healthcare: A lifecycle approach. Decis. Support Syst. 2014, 57, 387-394. [CrossRef]

30. Osterwalder, A.; Pigneur, Y.; Tucci, C.L. Clarifying Business Models: Origins, Present and Future of the Concept. Commun. Assoc. Inf. Syst. 2005, 16, 1-29. [CrossRef]

31. Pfannstiel, M.A.; Rasche, C. Service Business Model Innovation in Healthcare and Hospital Management; Springer Science and Business Media: Berlin, Germany, 2016.

32. Boons, F.; Montalvo, C.; Quist, J.; Wagner, M. Sustainable innovation, business frameworks and economic performance: An overview. J. Clean. Prod. 2013, 45, 1-8. [CrossRef]

33. Rosca, E.; Arnold, M.; Bendul, J.C. Business models for sustainable innovation-an empirical analysis of frugal products and services. J. Clean. Prod. 2016, 162, 133-145. [CrossRef]

34. Timmers, P. Business models for electronic markets. Electr. Markets 1998, 8, 3-8. [CrossRef]

35. Chesbrough, H.; Rosenbloom, R.S. The role of the business model in capturing value from innovation: Evidence from Xerox Corporation's technology spin-off companies. Ind. Corp. Chang. 2002, 11, 529-555. [CrossRef]

36. Zott, C.; Amit, R. Business Model. In Wiley Encyclopedia of Management; Wiley: Hoboken, NJ, USA, 2005.

37. Zott, C.; Amit, R. The fit between product market strategy and business model: Implications for firm performance. Strateg. Manag. J. 2008, 29, 1-26. [CrossRef]

38. Wikström, K.; Artto, K.; Kujala, J.; Söderlund, J. Business models in project business. Int. J. Proj. Manag. 2010, 28, 832-841. [CrossRef]

39. Amit, R.; Zott, C. Creating value through business model innovation. MIT Sloan Manag. Rev. 2012, 53, 41-49.

40. Drucker, P.F. Management Challenges for the 21st Century; Routledge: London, UK, 2007.

41. Block, D.J. Health care sustainability: Managing natural resources in value-based care. Phys. Lead. J. 2016, 3, 18 .

42. Janssen, M.; Moors, E.H. Caring for healthcare entrepreneurs-Towards successful entrepreneurial strategies for sustainable innovations in Dutch healthcare. Technol. Forecast. Soc. Chang. 2013, 80, 1360-1374. [CrossRef]

43. Christensen, C.M.; Grossman, J.H.; Hwang, J. The Innovator's Prescription. 2009. Available online: https: / / www.lumc.nl/sub/9300/att/1402060248071959.pdf (accessed on 2 November 2017).

44. Gallouj, F.; Weinstein, O. Innovation in services. Res. Policy 1997, 2, 537-556. [CrossRef]

45. Hwang, J.; Christensen, C.M. Disruptive innovation in health care delivery: A framework for business-model innovation. Health Aff. 2008, 27, 1329-1335. [CrossRef]

46. Björkdahl, J.; Holmén, M. Business model innovation-the challenges ahead. Int. J. Prod. Dev. 2013, 18, 213-225.

47. Faezipour, M.; Ferreira, S. A system dynamics perspective of patient satisfaction in healthcare. Procedia Comput. Sci. 2013, 16, 148-156. [CrossRef]

48. Dubosson-Torbay, M.; Osterwalder, A.; Pigneur, Y. E-business model design, classification, and measurements. Thunderbird Int. Bus. Rev. 2002, 44, 5-23. [CrossRef]

49. Van Putten, B.J.; Schief, M. The Relation between Dynamic Business Models and Business Cases. 2013. Available online: https://link.springer.com/chapter/10.1007/978-3-658-01171-0_8 (accessed on 3 November 2017).

50. Chesbrough, H.; Schwartz, K. Innovating business models with co-development partnerships. Res. Technol. Manag. 2007, 50, 55-59. [CrossRef]

51. Osterwalder, A.; Pigneur, Y. Business Model Generation; John Wiley \& Sons: Hoboken, NJ, USA, 2010.

52. Hossain, M.; Hossain, M. Business model innovation: Past research, current debates, and future directions. J. Strategy Manag. 2017, 10, 342-359. [CrossRef]

53. Wells, P. Alternative business models for a sustainable automotive industry. In System Innovation for Sustainability; Routledge: London, UK, 2017; pp. 90-108.

54. Lambert, S.C.; Davidson, R.A. Applications of the business model in studies of enterprise success, innovation and classification: An analysis of empirical research from 1996 to 2010. Eur. Manag. J. 2013, 31, 668-681. [CrossRef]

55. Keeley, L.; Walters, H.; Pikkel, R.; Quinn, B. Ten Types of Innovation: The Discipline of Building Breakthroughs; John Wiley \& Sons: Hoboken, NJ, USA, 2013.

56. Lüdeke-Freund, F. Towards a Conceptual Framework of Business Models for Sustainability. 2010. Available online: https: / / papers.ssrn.com/sol3/papers.cfm?abstract_id=2189922 (accessed on 9 May 2017). 
57. Schumpeter, J.A. The Theory of Economic Development. 1934. Available online: https://zyi2qxp18911. storage.googleapis.com/EgcLQbTRj8nbczWgg111.pdf (accessed on 16 June 2017).

58. Schumpeter, J.A. The Theory of Economic Development: An Inquiry into Profits, Capital, Credit, Interest, and the Business Cycle (1912/1934); Transaction Publishers: Piscataway, NJ, USA, 1982; p. 244.

59. Hekkert, M.P.; Negro, S.O. Functions of innovation systems as a framework to understand sustainable technological change: Empirical evidence for earlier claims. Technol. Forecast. Soc. Chang. 2009, 76, 584-594. [CrossRef]

60. Freeman, C.; Perez, C. Structural Crisis of Adjustment: Business Cycles and Investment Behaviour. 1988. Available online: http://www.carlotaperez.org/downloads/pubs/StructuralCrisesOfAdjustment.pdf (accessed on 22 May 2017).

61. Fussler, C.; James, P. A Breakthrough Discipline for Innovation and Sustainability; Pitman Publishing: London, UK, 1996.

62. Organisation for Economic Co-operation and Development (OECD). The Measurement of Scientific and Technological Activities: Proposed Guidelines for Collecting and Interpreting Technological Innovation Data: Oslo Manual; OECD: Paris, France, 1997.

63. Christensen, C.M.; Bohmer, R.; Kenagy, J. Will disruptive innovations cure health care? Harvard Bus. Rev. 2000, 78, 102-112.

64. Balan, P.; Lindsay, N. Developing Innovation Capability Measures for the Services Sector: An Exploratory Study; Swinburne UT: Hawthorn, VIC, Australia, 2007.

65. Tidd, J.; Bessant, J.; Pavitt, K. Gestão da Inovação[ManagingInnovation], 3rd ed.; Bookman: Porto Alegre, Brazil, 2008.

66. Gallouj, F.; Savona, M. Innovation in services: A review of the debate and a research agenda. J. Evol. Econ. 2009, 19, 149-172. [CrossRef]

67. Gunday, G.; Ulusoy, G.; Kilic, K.; Alpkan, L. Effects of innovation types on firm performance. Int. J. Prod. Econ. 2011, 133, 662-676. [CrossRef]

68. Ganter, A.; Hecker, A. Configurational paths to organizational innovation: Qualitative comparative analyses of antecedents and contingencies. J. Bus. Res. 2014, 67, 1285-1292. [CrossRef]

69. Porter, M.E. The competitive advantage of nations. Harvard Bus. Rev. 1990, 68, 73-93.

70. Chesbrough, H. Business model innovation: It's not just about technology anymore. Strategy Leadersh. 2007, 35, 12-17. [CrossRef]

71. Organisation for Economic Co-Operation and Development (OECD). Oslo Manual: Proposed Guidelines for Collecting and Interpreting Technological Innovation Data; OCDE Publishing: Paris, France, 2005.

72. Davila, T.; Epstein, M.J.; Shelton, R.D. The Creative Enterprise: Managing Innovative Organizations and People; Greenwood Publishing Group: Westport, CT, USA, 2006.

73. Linder, J.; Cantrell, S. Changing Business Models: Surveying the Landscape. 2000. Available online: http:// www.businessmodels.eu/images/banners / Articles/Linder_Cantrell.pdf (accessed on 27 September 2017).

74. Djellal, F.; Gallouj, F. Innovation in hospitals: A survey of the literature. Eur. J. Health Econ. 2007, 8, 181-193. [CrossRef] [PubMed]

75. Johnson, W.M. The time has come for business model innovation. Leader Leader 2010, 57, 6-10. [CrossRef]

76. Windrum, P.; Koch, P.M. Innovation in Public Sector Services: Entrepreneurship, Creativity and Management; Edward Elgar Publishing: Cheltenham, UK, 2008.

77. Anatole-Touzet, V.; Souffir, W. Innovation technologique, organisation du travail etgestion des compétences. Gest. Hosp. 1996, 354, 222-225.

78. Marody, M. Transition as a topic for sociological analysis. In Building Open Societies and Perspectives of Sociology in East-Central Europe; ISA: Krakow, Poland, 1996.

79. World Commission on Environment and Development (WCED). Our Common Future; Final Report of World Commission on Environment and Development; WCED: New York, NY, USA, 1987.

80. Loorbach, D.; Rotmans, J. Transition Management and Strategic Niche Management; Dutch Research Institute for Transitions: Rotterdam, The Netherlands, 2010.

81. Grin, J.; Rotmans, J.; Schot, J.; Geels, F.W.; Loorbach, D. Transitions to Sustainable Development; New Directions in the Study of Long Term Transformative Change; Routhledge: New York, NY, USA, 2010.

82. Smith, A.; Voß, J.P.; Grin, J. Innovation studies and sustainability transitions: The allure of the multi-level perspective and its challenges. Res. Policy 2010, 39, 435-448. [CrossRef] 
83. Meadowcroft, J. Engaging with the politics of sustainability transitions. Environ. Innov. Soc. Trans. 2011, 1, 70-75. [CrossRef]

84. Geels, F.W. The multi-level perspective on sustainability transitions: Responses to seven criticisms. Environ. Innov. Soc. Trans. 2011, 1, 24-40. [CrossRef]

85. Lawhon, M.; Murphy, J.T. Socio-technical regimes and sustainability transitions: Insights from political ecology. Prog. Hum. Geogr. 2012, 36, 354-378. [CrossRef]

86. Genus, A.; Coles, A.M. Rethinking the multi-level perspective of technological transitions. Res. Policy 2008, 37, 1436-1445. [CrossRef]

87. Weber, K.M.; Rohracher, H. Legitimizing research, technology and innovation policies for transformative change: Combining insights from innovation systems and multi-level perspective in a comprehensive 'failures' framework. Res. Policy 2012, 41, 1037-1047. [CrossRef]

88. Kemp, R.; Loorbach, D. Governance for Sustainability through Transition Management. 2003. Available online: https://www.researchgate.net/profile/Derk_Loorbach/publication/2883708_Governance_for_ Sustainability_Through_Transition_Management/links/02e7e51a74226aa52c000000/Governance-forSustainability-Through-Transition-Management.pdf (accessed on 28 September 2017).

89. Farla, J.; Markard, J.; Raven, R.; Coenen, L. Sustainability transitions in the making: A closer look at actors, strategies and resources. Technol. Forecast. Soc. Chang. 2012, 79, 991-998. [CrossRef]

90. Kaissi, A.A.; Begun, J.W.; Welson, T. Strategic planning processes and hospital financial performance. J. Healthc. Manag. 2008, 53, 197-208. [CrossRef] [PubMed]

91. Cleven, A.; Mettler, T.; Rohner, P.; Winter, R. Healthcare quality innovation and performance through process orientation: Evidence from general hospitals in Switzerland. Technol. Forecast. Soc. Chang. 2016, 113, 386-395. [CrossRef]

92. Barbier, E.B. Transaction costs and the transition to environmentally sustainable development. Environ. Innov. Soc. Trans. 2011, 1, 58-69. [CrossRef]

93. Markard, J.; Raven, R.; Truffer, B. Sustainability transitions: An emerging field of research and its prospects. Res. Policy 2012, 41, 955-967. [CrossRef]

94. Smith, A.; Raven, R. What is protective space? Reconsidering niches in transitions to sustainability. Res. Policy 2012, 41, 1025-1036. [CrossRef]

95. Martin, C.J. The sharing economy: A pathway to sustainability or a nightmarish form of neoliberal capitalism? Ecol. Econ. 2016, 121, 149-159. [CrossRef] 